\title{
Pengaruh Penerapan Syariat Islam Sebagai Preferensi Orang Tua di Kabupaten Aceh Tengah dalam Memilih Lembaga Pendidikan Formal (Study Deskriptif Komparatif: Sekolah Umum, Madrasah dan Pesantren)
}

\author{
Aida Fitri, Leni Agustina Daulay \\ Sekolah Tinggi Agama Islam Negeri Gajah Putih Takengon \\ agustina_leni@yahoo.com
}

\begin{abstract}
This research aims to know the influence of the application of the Shariah as the preferences of older people in Central Aceh in choosing formal education instutions. This research is quantitative descriptive research. The results of this research show that the factor knowledge of parents reagarding Islamic Jurisrudence and its application as well as economic, educational background of parents dealing with the positive decision of the parents send the children in public school, boarding schools and madrasah in Central Aceh. The next factor is the parents knowledge about Islamic Jurisrudence and its application as well as economic, educational background of parents can explain its effect on the dependent variable i.e. decisions parents send children in public school, boarding schools and madrasah. Based on the test silmutaneously demonstrated knowledge factors parents regarding Islamic Jurisrudence and its application as well as educational background, economically significant influential parents against decisions parents send children in public school, boarding schools and madrasah in Central Aceh. Then test the partial basis for each variable that is knowledge og the elderly on Islamic Juristudence and its application as well as educational background, economically significant influential parents against decisions parents send children at public school, boarding schools and madrasah in Central Aceh.
\end{abstract}

Keywords: Islamic Jurisrudence, Public School, Boarding School and Madrasah

Abstrak: Penelitian ini bertujuan untuk mengetahui pengaruh penerapan Syariat Islam sebagai preferensi orang tua di Kabupaten Aceh Tengah dalam memilih lembaga pendidikan formal. Penelitian

Belajea: Jurnal Pendidikan Islam, Vol. 4, No. 1, 2019; 49-60

p-ISSN 2548-3390; e-ISSN 2548-3404, DOI: 10.29240/belajea.v4i1.730

available online at: http://journal.staincurup.ac.id/index.php/belajea 
ini merupakan penelitian deskriptif kuantitatif. Dari hasil penelitian menjelaskan bahwa faktor pengetahuan orang tua mengenai Syariat Islam dan penerapannya serta latar belakang pendidikan, ekonomi orang tua berhubungan positif dengan keputusan orang tua menyekolahkan anak di sekolah umum, pondok pesantren dan madrasah di Aceh Tengah. Selanjutnya faktor pengetahuan orang tua mengenai Syariat Islam dan penerapannya serta latar belakang pendidikan, ekonomi orang tua dapat menjelaskan pengaruhnya terhadap variabel dependen yaitu keputusan orang tua menyekolahkan anak di sekolah umum, pondok pesantren dan madrasah di Aceh Tengah. Berdasarkan uji secara simultan menunjukkan faktor pengetahuan orang tua mengenai Syariat Islam dan penerapannya serta latar belakang pendidikan, ekonomi orang tua berpengaruh signifikan terhadap keputusan orang tua menyekolahkan anak di sekolah umum, pondok pesantren dan madrasah di Aceh Tengah. Kemudian uji secara parsial untuk masing-masing variabel yaitu pengetahuan orang tua mengenai Syariat Islam dan penerapannya serta latar belakang pendidikan, ekonomi orang tua berpengaruh signifikan terhadap keputusan orang tua menyekolahkan anak di sekolah umum, pondok pesantren dan madrasah di Aceh Tengah.

Kata kunci: Syariat Islam, Sekolah Umum, Pondok Pesantren dan Madrasah

\section{Pendahuluan}

Kesadaran bangsa Indonesia akan arti penting menuntun ilmu dalam penyelenggaraan pendidikan, ternyata belum diiringi dengan kecerdasannya dalam menyelenggarakan dan mengelola pendidikan. Sistem pendidikan yang diselenggarakan selama ini sangat bersifat dikotomis; pendidikan umum (SD, SLTP, SMU, SMK, Universitas umum, dan lain-lain) versus pendidikan keagamaan (MI, MTs, MA, Pesantren, pelajaran umum versus pelajaran agama; sampai kepada penyelenggara pendidikan antara Kementerian Pendidikan Nasional dan Budaya yang menyelenggarakan pendidikan umum dan Kementerian Agama yang menyelenggarakan pendidikan keagamaan.

Upaya untuk menghilangkan atau menghapus praktek dikotomis antara sekolah umum dan sekolah agama, sudah banyak dilakukan. 
Departemen Pendidikan dan Kebudayaan ketika itu telah memasukkan pendidikan agama sebagai mata pelajaran yang harus diajarkan di sekolah, tetapi alokasi waktu yang diberikan sangat minim, yaitu dua jam seminggu. Memang ada usaha-usaha yang dilakukan oleh Departemen Agama untuk menambah jam pelajaran menjadi enam jam per minggu pada tahun 1970, tetapi oleh Departemen Pendidikan dan Kebudayaan usulan tersebut tidak disetujui ${ }^{1}$. Untuk pendidikan di lingkungan madrasah dan pesantren, Departemen Agama telah berusaha untuk tidak mempertajam perbedaan antara pelajaran agama dan pelajaran umum, yaitu dengan mengelurkan Surat Keputusan Bersama (SKB) antara Menteri Agama dan Menteri Pendidikan dan Budaya dan Menteri Dalam Negeri tahun 1975. Kurikulum Madrasah yang baku dari Departemen Agama tentang perbandingan mata pelajaran umum dan pelajaran agama $70 \%: 30 \%$. $^{2}$

Penyelenggaraan pendidikan yang ada di Aceh memiliki kekhususan dengan diterapkan UU 44/1999 tentang Keistimewaan Aceh dan UU 18/2001 tentang Otonomi Khusus. Kedua UU itu memberi posisi istimewa untuk pendidikan.

Secara umum, Pasal 215 UUPA menyebutkan bahwa pendidikan yang diselenggarakan di Aceh merupakan satu kesatuan dengan sistem pendidikan nasional yang disesuaikan dengan karakteristik, potensi, dan kebutuhan masyarakat setempat. Qanun menyebutkan bahwa pendidikan Aceh berasaskan: keislaman, kebangsaan, keacehan, kebenaran, kemanusiaan, keadilan, kemanfaatan, keterjangkauan, profesionalitas, keteladanan, keanekaragaman, serta nondiskriminasi. Pasal 1 Qanun, Pendidikan Dayah adalah satuan pendidikan yang khusus yang menyelenggarakan pendidikan agama Islam yang bertujuan untuk mengembangkan kemampuan, pengetahuan, dan keterampilan peserta didik untuk menjadi ahli ilmu agama Islam (mufaqqih fiddin) atau menjadi muslim yang memiliki keterampilan dan keahlian membangun kehidupan yang Islami ${ }^{3}$.

Hal ini sejalan dalam perundang-undangan yang berlaku di Indonesia dan Aceh, Syariat Islam didefinisikan sebagai tuntunan ajaran Islam dalam semua segi kehidupan. Tuntunan tersebut dalam perundang-undangan diuraikan

${ }^{1}$ Karel A. Steenbrink. Pesantren Madrasah Sekolah Dalam kurun Waktu Modren. Jakarta, LP3ES.

${ }^{2}$ Marwan Sarijo, Bunga Rampai Pendidikan Agama Islam, (Jakarta: CV. Amisco, 1996)

${ }^{3}$ Mukhlisuddin Ilyas, Pendidikan Dayah Setelah Undang-Undang Pemerintah Aceh, Kanun Jurnal Ilmu Hukum, Vol. 18, No. 3, (Desember 2016). 
ke dalam 13 unsur utama, yaitu aqidah, ibadah, mu'amalah, akhlak, pendidikan dan dakwah Islamiyah/amar makruf, nabi munkar, baitul mal, kemasyarakatan, syiar Islam, Pembelaan Islam, Qadha, Jinayat, Munakahat dan Mawaris .

Namun kenyataan di lapangan syariat Islam di Aceh selama ini masih kurang menyentuh ranah pendidikan. Hal ini diperkuat oleh Mukhlisuddin Ilyas menyatakan beberapa catatan yang mesti menjadi diskursus pendidikan dayah di Aceh, dalam konteks legislasi terutama setel ah reformasi, pendidikan dayah (dan dayah itu sendiri) menjadi "garapan" pemerintah, bergeser dari berbasis community based, kepada government based. . Hal senada juga disampaikan oleh Muakhir Zakaria yang menyatakan bahwa saat ini, kita tidak bisa lagi menyalahkan pemerintah pusat jika pendidikan di Aceh yang bersyariat belum sepenuhnya Islami, hanya sebatas konsep dan minim implementasi disarankan harus berani membuat kurikulum pendidikan Islami di Aceh yang bermutu sehingga terbentuk nilai-nilai dan karakter keislaman pada anak didik ${ }^{6}$.

Aceh Tengah merupakan salah satu kabupaten yang ada di Propinsi Aceh. Aceh Tengah juga memakai Qanun pendidikan dalam penyelenggaraan pendidikannya yang memiliki 17 pesantren (1.966 santri), 56 sekolah (11.892 siswa) dan 22 madrasah (5.943 siswa) ${ }^{7}$.

Dari hasil wawancara yang dilakukan penulis terhadap 10 orang tua menyimpulkan bahwa ada keinginan orang tua untuk memasukkan anaknya di pesantren tetapi terhalang masalah dana, orang tua yang sudah memasukkan anaknya di pesantren dengan alasan untuk menghindari anaknya dari pergaulan bebas, penyalahgunaan obat-obatan terlarang dan menginginkan anaknya kelak menjadi anak yang sholeh/sholeha yang akan mendoakan mereka ketika meninggal dunia. Sedangkan orang tua yang menyekolahkan anaknya di madrasah karena menginginkan anaknya mendapat pelajaran agama lebih banyak dari sekolah umum yang biayanya tidak semahal pondok pesantren.

4 Muslim Ibrahim, Implementasi Syariat Islam Dan Kearifan Lokal Di Aceh, http://www.santridayah.com/2013/03/implementasi-syariat-islam-dan-kearifan-lokal-di-aceh. (Diakses pada 14 Juli 2017).

${ }^{5}$ Mukhlisuddin Ilyas, Pendidikan Dayah Setelah Undang-Undang Pemerintab Aceh, Kanun Jurnal Ilmu Hukum,Vol. 18, No. 3, (Desember 2016).

${ }^{6}$ Muakhir Zakaria. Pendidikan Di Aceb Masib Sebatas Konsep. http://www.lintasnasional.com/2016/09/29/pendidikan-islami-di-aceh-masih-sebatas-konsep/ (Diakses pada 14 Juli 2017).

${ }^{7}$ Badan Pusat Statistik, Aceh Tengah dalam Angka Tahun, 2016. 
Kondisi di atas, menunjukkan bahwa adanya ketakutan orang tua terhadap perilaku anak yang berimplikasi dari sistem pendidikan sekolah yang dikelola oleh pemerintah (Kemendikbud) yang kurang menumbuhkan kesadaran akan nilai-nilai luhur (aspek rohani) yang menjadi motor penggerak perkembangan peserta didik ke arah hidup yang lebih manusiawi. Adanya kenakalan remaja, tawuran antar pelajar, terlibatnya siswa dengan obat-obatan terlarang, minuman keras, pergaulan bebas, dan sebagainya dinilai sebagai kegagalan pihak sekolah dalam menanamkan nilai-nilai moral dan akhlak ke dalam diri siswa. Itu berarti, pendidikan agama yang dua jam, serta pendidikan moral dan pendidikan nilai lainnya yang diberikan sekolah tersebut hampir tidak memberikan pengaruh apa-apa pada diri peserta didik.

Kebalikan dari sistem pendidikan sekolah, pesantren, salah satu bentuk lembaga pendidikan Islam, dikenal sebagai lembaga pendidikan yang mampu melahirkan santri-santri (peserta didik) yang menguasai ilmu-ilmu agama serta menghayati dan mengamalkan ajaran-ajarannya dengan ikhlas, memiliki akhlak yang luhur, berjiwa besar, hidup sederhana, dan lain sebagainya. Karena semuanya itu memang menjadi fokus dan tujuan dari pendidikan pesantren itu sendiri.

Terdapat kelemahan di pesantren dapat dijelaskan bahwa; pertama, santri yang dilahirkan pesantren adalah santri yang 'alim dalam soal agama tapi kurang dan bingung apabila dihadapkan dengan persoalan dunia. Padahal untuk menguasai dunia, "ilmu-ilmu umum" merupakan prasyarat yang harus dimiliki. Kedua, pemahaman "ulama" yang menjadi target atau tujuan pendidikan pesantren harus ditinjau ulang.

Dari permasalahan di atas penulis merasa tertarik melakukan penelitian dengan judul "Pengaruh Syariat Islam di Aceh Sebagai Preferensi Orang Tua Kabupaten Aceh Tengah dalam Memilih Lembaga Pendidikan Formal".

Metode penelitian ini adalah penelitian deskriptif dengan pendekatan kalitatif dan kuantitatif. Objek penelitian ini adalah 100 responden orang tua siswa yang sekolah di sekolah umum, madrasah dan pondok pesantren dan ruang lingkup penelitian ini terbatas pada penerapan Syariat Islam. Teknik pengumpulan data dalam penelitian ini menggunakan kuisioner, yaitu daftar pertanyaan yang didistribusikan untuk diisi dan dikembalikan atau dapat juga

8 Amrizal, Sekolah Versus Pesantren Sebuah Perbandingan Menuju Format Baru Mainstream Lembaga Pendidikan Nasional Peniada, Jurnal Sosial Budaya Volume 8 no.1 (2011) 
dijawab di bawah pengawasan peneliti, selanjutnya dilakukan analisis data dengan menggunakan peralatan analisis regresi linier berganda.

\section{Analisis Pengetahuan Orang Tua Mengenai Syariat Islam dan Penerapannya}

Dalam analisis pengetahuan orang tua mengenai Syariat Islam dan penerapannya akan dibahas mengenai pengetahuan orang tua tentang pentingnya memberikan pendidikan agama Islam kepada anak dirumah dan penerapannya dalam kehidupan sehari-hari mulai dari mengingatkan anak untuk shalat lima waktu, shalat berjamaah, membaca buku agama Islam, membiasakan untuk bersedekah, membaca Al-Qur'an setelah shalat (Magrib atau Isya).

Pengetahuan orang tua tentang syariat Islam dan adanya unsur pendidikan dalam syariat Islam seluruh orang tua baik yang anaknya sekolah di sekolah umum, pondok pesantren dan madrasah menjawab 100\% ya yang menunjukkan bahwa orang tua mengetahui tentang prinsip syariat Islam dan mengetahui dalam syariat Islam ada Unsur Pendidikan. Sedangkan penerapannya dapat dilihat pada analisis latar belakang dan ekonomi orang tua. Dalam analisis latar belakang dan ekonomi orang tua akan dibahas mengenai tingkatan pendidikan orang tua dan ekonomi orang tua serta jumlah anggota keluarga. Tingkatan pendidikan orang tua pada sekolah umum 55\% orang tua berpendidikan sarjana (S-1), 38,4\% berpendidikan setara SMA/MA dan 6,9\% berpendidikan SMP. Pada pondok pesantren $44,7 \%$ orang tua berpendidikan SMA/MA, 20,4\% berpendidikan SMP/MTs. Serta di madrasah 18,5\% orang tua berpendidikan sarjana (S-1), 57,1\% berpendidikan SMA/MA dan 21,5\% berpendidikan SMP/MTs.

\section{Uji Multikolonieritas}

Uji multikolonieritas untuk melihat apakah adanya korelasi antar variabel bebas (independen) pada model regresi berganda. Model regresi yang baik adalah tidak terjadinya multikolonieritas antar variabel independen. Untuk menguji multikolonieritas pada penelitian ini dengan melihat nilai tolerance dan variance inflation factor (VIF) dengan nilai cut off yang umum dipakai yaitu tolerance $<0,10$ atau sama dengan nilai $\mathrm{VIF}>10$.

Adapun hasil uji multikolonieritas dapat dilihat pada perolehan nilai yaitu tidak satupun nilai tolerance masing-masing variabel independen ini kurang dari 0,10 atau nilai VIF lebih besar dari 10. Berdasarkan kriteria pengambilan 
keputusan dalam pengujian multikolonieritas, maka dapat diambil kesimpulan bahwa tidak terdapat multikolonieritas dalam model regresi, dengan demikian model regresi masuk dalam kategori sebagai model regresi yang baik dan lolos dari uji asumsi klasik. Dengan demikian data tersebut dapat digunakan dalam penelitian ini.

\section{Uji Heteroskedastisitas}

Uji heteroskedastisitas dilakukan untuk menguji apakah dalam model regresi ketidaksamaan variance dari residual satu pengamatan kepengamatan yang lain. Jika pengamatan variance dari residual ke pengamatan lain tetap maka disebut homokedastisitas dan jika berbeda disebut heterokedastisitas. Apabila dalam model terbebas dari heteroskedastisitas maka model regresi bersifat homoskedastisitas dan model ini termasuk dalam katagori model yang baik.

Untuk mendeteksi heteroskedastisitas dalam penelitian ini dengan melihat grafik scatterplot antara nilai prediksi variabel terikat (independen) yaitu ZPRED dengan residualnya SRESID. Terdeteksi ada tidaknya heteroskedastisitas dapat melihat ada tidaknya pola tertentu pada grafik scaterplot antara SRESID dan ZPRED dimana sumbu Y adalah Y yang telah diprediksi, dan sumbu $\mathrm{X}$ adalah residual ( $\mathrm{Y}$ prediksi-Y sesungguhnya yang telah di-studentized. Jika ada pola tertentu, seperti titik yang ada membentuk pola tertentu yang teratur (bergelombang, melebar kemudian menyempit), maka mengindentifikasikan telah terjadi heteroskedastisitas. Jika tidak ada pola yang jelas, serta titik menyebar di atas dan di bawah angka 0 pada sumbu $\mathrm{Y}$, maka tidak terjadi heteroskedastisitas dengan kata lain terjadinya homoskedastisitas. Berdasarkan titik-titik menyebar secara acak serta tersebar baik di atas maupun di bawah angka 0 pada sumbu Y. Dengan demikian dapat disimpulkan bahwa tidak terjadi heteroskedastisitas pada model regresi ini atau dengan kata lain terjadi homoskedastisitas sehingga model regresi layak dipakai untuk memprediksi variabel independen.

\section{Analisis Faktor-Faktor Yang Mempengaruhi Keputusan Orang Tua Menyekolahkan Anak.}

Untuk mengetahui hasil faktor-faktor yang mempengaruhi keputusan orang tua menyekolahkan anak di sekolah umum, pondok pesantren dan 
madrasah di Aceh Tengah dapat dilihat dari output regresi linear berganda pada Tabel 3 di bawah ini.

Tabel 3. Faktor-Faktor Yang Mempengaruhi Keputusan Menyekolahkan Anak di Sekolah

Umum, Pondok Pesantren dan Madrasah di Aceh Tengah

\begin{tabular}{|c|c|c|c|c|c|}
\hline Nama Variabel & $\mathrm{B}$ & Std Error & t hitung & $\mathrm{t}$ tabel & Sig \\
\hline Konstanta (a) & 1,621 & 0,463 & 3,503 & 1,9799 & 0,001 \\
\hline \begin{tabular}{lr} 
Faktor & \multicolumn{2}{r}{ pengetahuan } \\
orang tua mengenai \\
Syariat Islam dan \\
penerapannya
\end{tabular} & 0,113 & 0,120 & 2,939 & 1,9799 & 0,000 \\
\hline $\begin{array}{ll}\text { Faktor latar } & \text { belakang } \\
\text { pendidikan, } & \text { ekonomi } \\
\text { orang tua } & \end{array}$ & 0,225 & 0,153 & 2,471 & 1,9799 & 0,000 \\
\hline $\begin{array}{lrr}\text { Koefisien } & \text { Korelasi } & (\mathrm{R}) \\
=0,535 & & \\
\text { Koefisien } & \text { Determinasi } \\
\left(\mathrm{R}^{2}\right)=0,934 & & \\
\text { Adjusted } & \\
=0,773 & \\
\text { Fhitung } & \\
=15,633 & \\
\text { Ftabel } & \\
=1,39 & \\
\text { F } & \\
=0,000 & \text { sig } \\
& \end{array}$ & \multicolumn{5}{|l|}{$\begin{array}{l}\text { Fakto } \\
\text { Islam } \\
\text { pendi } \\
\text { b. De } \\
\text { Ke }\end{array}$} \\
\hline
\end{tabular}

Berdasarkan hasil output regresi melalui program SPSS yang terlihat pada Tabel 3 di atas, maka dapat dimasukkan dalam persamaan regresi berganda sebagai berikut:

$\mathrm{Y}=1,631+0,113 \mathrm{X} 1+0,225 \mathrm{X} 2$

Hasil persamaan regresi linear berganda di atas diperoleh nilai konstanta (a) adalah sebesar 1,631 yang berarti disaat variabel independen yaitu faktor pengetahuan orang tua mengenai Syariat Islam dan penerapannya, latar belakang pendidikan, ekonomi orang tua bernilai 0 (nol) maka keputusan orang tua tetap sebesar 1,631. Kemudian nilai koefisien faktor pengetahuan orang tua mengenai Syariat Islam dan penerapannya sebesar 0,113 , nilai ini bermakna 
apabila meningkat $1 \%$ maka keputusan orang tua akan meningkat sebesar 0,113 . Hasil koefisien ini menunjukkan pengaruh positif yang berarti semakin meningkat variabel maka semakin meningkat pula keputusan orang tua.

Selanjutnya nilai koefisien latar belakang pendidikan, ekonomi orang tua sebesar 0,225, ini menunjukkan apabila kelas sosial meningkat 1\% maka keputusan akan meningkat sebesar 0,225. Hasil koefisien ini juga berpengaruh positif yang berarti semakin meningkat variabel nilai koefisien latar belakang pendidikan, ekonomi orang tua maka semakin meningkat pula keputusan orang tua.

Pada Tabel 3 di atas juga diketahui nilai koefisien korelasi (R) sebesar 0,535. Nilai ini menunjukkan bahwa terdapat hubungan variabel independen yaitu faktor pengetahuan orang tua mengenai Syariat Islam dan penerapannya serta latar belakang pendidikan, ekonomi orang tua terhadap variabel dependen yaitu keputusan menyekolahkan anak di sekolah umum, pondok pesantren dan madrasah di Aceh Tengah sebesar 53,5\%.

Selanjutnya nilai koefisien determinasi $\left(\mathrm{R}^{2}\right)$ diperoleh nilai sebesar 0,934 , nilai ini menunjukkan bahwa variabel independen yang terdiri dari faktor pengetahuan orang tua mengenai Syariat Islam dan penerapannya serta latar belakang pendidikan, ekonomi orang tua dapat menjelaskan pengaruhnya terhadap variabel dependen yaitu keputusan menyekolahkan anak di sekolah umum, pondok pesantren dan madrasah di Aceh Tengah sebesar 93,4\%, sementara sisanya sebesar $6,6 \%$ dipengaruhi oleh variabel lain yang tidak dimasukkan dalam model penelitian ini, seperti fasilitas sekolah, akreditasi, lokasi sekolah dan variabel lainnya.

\section{Pengujian Hipotesis}

1. Uji Simultan (Uji-F)

Uji-F dilakukan untuk menguji apakah semua variabel independen berpengaruh secara simultan atau bersama-sama terhadap variabel dependen secara statistik atau tidak. Pengujian yang digunakan dalam penelitian ini adalah dengan ketentuan jika $\mathrm{F}^{\text {hitung }}>\mathrm{F}^{\text {tabel }}$ pada $\alpha=0,05$ dengan taraf kepercayaan 95\%. maka menerima $\mathrm{H}^{3}$ dan sebaliknya jika $\mathrm{F}^{\text {hitung }}<\mathrm{F}$ tabel pada $\alpha=0,05$ maka menolak $\mathrm{H}^{3}$. 
Berdasarkan hasil pengujian secara simultan yang terlihat pada Tabel 3 di atas diperoleh nilai $\mathrm{F}^{\text {hitung }}$ sebesar 15,633 dengan nilai signifikansi sebesar 0,000 pada taraf kepercayaan 95\%. Sedangkan Ftabel $\mathrm{N}^{2}=\mathrm{n}-\mathrm{k}-1$ (100-5-1=94) dan $\mathrm{N}$ $1=\mathrm{k}-1(5-1=4)$ diperoleh nilai sebesar 1,39 pada $\alpha=0,05$. Dengan demikian $F^{\text {hitung }}>$ F tabel, yaitu 85,181 $>2,47$ dan nilai signifikansi sebesar 0,000, nilai ini jauh di bawah 0,05 . Maka keputusannya adalah menerima $\mathrm{H}^{5}$, yang berarti secara simultan faktor pengetahuan orang tua mengenai Syariat Islam dan penerapannya serta latar belakang pendidikan, ekonomi orang tua berpengaruh signifikan terhadap keputusan menyekolahkan anak di sekolah umum, pondok pesantren dan madrasah di Aceh Tengah.

2. Uji Parsial (Uji-t)

Uji-t dilakukan untuk menguji apakah ada pengaruh variabel independen secara parsial atau individul terhadap variabel dependen secara statistik. Pengujian yang digunakan adalah dengan ketentuan jika $\mathrm{t}^{\text {hitung }}>\mathrm{t}^{\text {tabel }}$ pada $\alpha=$ 0,05 maka menerima $\mathrm{H}^{1}, \mathrm{H}^{2}, \mathrm{H}^{3}$ dan $\mathrm{H}^{4}$, dan sebaliknya jika $\mathrm{t}^{\text {hitung }}<\mathrm{t}^{\text {tabel }}$ pada $\alpha=0,05$ maka menolak $\mathrm{H}^{1}, \mathrm{H}^{2}, \mathrm{H}^{3}$ dan $\mathrm{H}^{4}$.

Berdasarkan hasil pengujian secara parsial atau individual sebagaimana terlihat pada Tabel 3 di atas bahwa variabel pengetahuan orang tua mengenai Syariat Islam dan penerapannya memiliki nilai thitung sebesar 3,503 dengan nilai signifikansi 0,002, sementara nilai ttabel dengan $(\mathrm{df})=\mathrm{n}-\mathrm{k}-1 \quad(100-3-1=96)$ pada $\alpha=0,05$ diperoleh nilai sebesar 2,003, Dengan demikian $\mathrm{t}^{\text {hitung }}>\mathrm{t}^{\text {tabel }}$, yaitu 3,503 > 1,9799 dan nilai signifikansi sebesar 0,001, nilai ini jauh di bawah 0,05. Maka keputusannya adalah menerima $\mathrm{H}^{1}$, yang berarti secara parsial faktor pengetahuan orang tua mengenai Syariat Islam dan penerapannya berpengaruh signifikan terhadap keputusan orang tua menyekolahkan anak di sekolah umum, pondok pesantren dan madrasah di Aceh Tengah.

Selanjutnya variabel latar belakang pendidikan, ekonomi orang tua mempunyai nilai thitung sebesar 2,939 dengan nilai signifikansi 0.000 , sedangkan nilai ttabel sebesar 1,9799 dengan demikian $\mathrm{t}^{\text {hitung }}>\mathrm{t}^{\text {tabel }}$, yaitu 2,939 $>1,9799$ dan nilai signifikansi sebesar 0,000, nilai ini di bawah nilai 0,05. Maka 
keputusannya adalah menerima $\mathrm{H}^{2}$, yang berarti secara parsial latar belakang pendidikan, ekonomi orang tua berpengaruh signifikan terhadap menyekolahkan anak di sekolah umum, pondok pesantren dan madrasah di Aceh Tengah.

\section{Penutup}

Hasil penelitian ini menunjukkan bahwa faktor pengetahuan orang tua mengenai Syariat Islam dan penerapannya serta latar belakang pendidikan, ekonomi orang tua berhubungan positif dengan keputusan orang tua menyekolahkan anak di sekolah umum, pondok pesantren dan madrasah di Aceh Tengah. Selanjutnya faktor pengetahuan orang tua mengenai Syariat Islam dan penerapannya serta latar belakang pendidikan, ekonomi orang tua dapat menjelaskan pengaruhnya terhadap variabel dependen yaitu keputusan orang tua menyekolahkan anak di sekolah umum, pondok pesantren dan madrasah di Aceh Tengah.

Berdasarkan uji secara simultan menunjukkan faktor pengetahuan orang tua mengenai Syariat Islam dan penerapannya serta latar belakang pendidikan, ekonomi orang tua berpengaruh signifikan terhadap keputusan orang tua menyekolahkan anak di sekolah umum, pondok pesantren dan madrasah di Aceh Tengah. Kemudian uji secara parsial untuk masing-masing variabel yaitu pengetahuan orang tua mengenai Syariat Islam dan penerapannya serta latar belakang pendidikan, ekonomi orang tua berpengaruh signifikan terhadap keputusan orang tua menyekolahkan anak di sekolah umum, pondok pesantren dan madrasah di Aceh Tengah.

\section{Bibliografi}

Amrizal, Sekolah Versus Pesantren Sebuah Perbandingan Menuju Format Baru Mainstream Lembaga Pendidikan Nasional Peniada, Jurnal Sosial Budaya, Vol. 8, No.1, 2011

Arikunto, Suharsimi, Manajemen Penelitian, Jakarta: PT. Rineka Cipta, 1997

Asmani, Jamal Ma'mur, Kiat Melahirkan Madrasah Unggulan: Merintis dan Mengelola Madrasah yang Kompetitif, (Yogyakarta: Diva Press, 2013

Badan Pusat Statistik, Aceh Tengah dalam Angka Tahun 2016

Daulay, Haidar Putra, Historisitas dan Eksistensi: Pesantren, sekolah dan Madrasah, Yogyakarta: Tiara Wacana, 2001 
60 Belajea : Jurnal Pendidikan Islam, Vol. 4, No. 01, 2019

Sejarah Pertumbuhan dan Pembaharuan Pendidikan Islam di Indonesia, (Jakarta: Kencana Prenada Media Group. 2009

Departemen Agama, Standarisasi Pengajaran Agama di Pondok Pesantren, 1981

Dhofier, Zamakhsyari, Tradisi Pesantren: Studi Tentang Pandangan Hidup Kyai, Jakarta: LP3ES, 1994)

Karel A. Steenbrink. Pesantren Madrasah Sekolah Dalam kurun Waktu Modren. Jakarta, LP3ES.

Marwan Sarijo, Bunga Rampai Pendidikan Agama Islam, (Jakarta: CV. Amisco, 1996

Mujiburrahman, Pendidikan Berbasis Syariat Islam Di Aceh, (Banda Aceh: Dinas Syariat Islam, 2011)

Mukhlisuddin Ilyas, Pendidikan Dayah Setelah Undang-Undang Pemerintah Aceh, Kanun Jurnal Ilmu Hukum,Vol. 18, No. 3, (Desember, 2016).

Poerwadarminta, Kamus Umum Bahasa Indonesia, Jakarta: Balai Pustaka, 1976

Singarimbun, Masri, Metode Penelitian Survai, Jakarta: LP3ES, 1995 